\title{
PERANCANGAN WEBSITE PENJUALAN PADA TOKO AUTOMOTIVE FILTER MOBIL
}

\author{
Ika Yuniva \\ Program Studi Sistem Informasi Universitas Bina Sarana Informatika \\ e-mail: ika.iya@bsi.ac.id
}

\begin{abstract}
Abstrak
Toko Automotive Filter Mobil merupakan usaha bisnis dibidang penjualan filter mobil meliputi filter oli, filter udara dan filter bahan bakar.Toko Automotive Filter Mobil saat ini belum memiliki sebuah website untuk memasarkan penjualan filter mobil. Sistem transaksi penjualan filter mobil serta pembuatan laporan pemesanan dan penjualan masih konvensional sehingga memungkinkan adanya kehilangan data, sehingga diperlukan sebuah media penyimpanan yang baik dan dikelola dengan baik menggunakan sebuah aplikasi website. Tujuan penelitian ini penulis ingin membuat sebuah rancangan website penjualan filter mobil untuk mempermudah Toko Automotive Filter Mobil dalam mengelola transaksi penjualan. Bentuk pengumpulan data penelitian ini menggunakan metode observasi dan studi pustaka. Metode pengembangan perangkat lunak penulis menggunakan metode waterfall. Bahasa pemograman dalam merancang website penjualan filter mobil menggunakan PHP dan HTML. Sedangkan untuk database penulis gunakan MySQL. Hasil dari penelitian ini diharapkan akan menghasilkan sebuah website penjualan filter mobil yang akan membantu Toko Automotive Filter Mobil dalam mengelola transaksi penjualan dan laporan pemesanan filter mobil.
\end{abstract}

Kata Kunci-Penjualan, Filter Mobil, Website

\begin{abstract}
The Car Automotive Filter Store is a business venture in the sale of car filters including oil filters, air filters and fuel filters. Automotive Filter Car Stores currently do not have a website to market car filter sales. The car filter sales transaction system as well as making orders and sales reports are still conventional so as to allow data loss, so that a good storage media is needed and properly managed using a website application. The purpose of this study the author wants to make a design website for car filter sales to facilitate Automotive Filter Car Stores in managing sales transactions. The form of data collection in this study uses the method of observation and literature. The author's software development method uses the waterfall method. Programming language in designing car sales website filters using PHP and HTML. As for the database, I use MySQL. The results of this study are expected to produce a car filter sales website that will help Automotive Car Filter Stores in managing sales transactions and car filter order reports
\end{abstract}

Keywords—Sales, Car Filter, Website 


\section{Pendahuluan}

Toko Automotive filter mobil menjual beberapa jenis filter mobil seperti filter oli, filter udara dan filter bahan bakar. Beberapa Toko Automotive Filter Mobil dalam memasarkan produk filter mobil sangatlah bersaing. Sehingga diperlukan sebuah strategi dalam memasarkan dan menjual filter mobil yaitu dengan memanfaatkan website. Selama ini Toko Automotive Filter Mobil sistem penjualannya masih konvensional, dalam hal ini pelangggan datang langsung ke Toko Automotive Filter Mobil untuk melakukan pemesanan dan pembelian filter mobil. Selain itu dengan sistem konvensional, mengalami kesulitan untuk memasarkan produk filter mobil ke beberapa daerah dan pencatatan dalam transaksi penjualannya pun masih manual menggunakan media kertas. Untuk membantu Toko Automotive Filter Mobil dalam memasarkan dan menjual filter mobil, maka penulis merancang sebuah Website.

\section{PERMASALAHAN}

Adapun permasalahan dari penelitian ini adalah :

1. Dalam proses penjualan dan pemesanan filter mobil masih konvensional, pelanggan datang langsung ke Toko Automotive Filter Mobil.

2. Pencatatan transaksi penjualan dan pembuatan laporan pemesanan masih manual menggunakan media kertas.

\section{TUJUAN PENELITIAN}

Tujuan dari penelitian ini yaitu :

1. Merancang sebuah website pada Toko Automotive Filter Mobil untuk memudahkan dalam proses penjualan dan pemesanan filter mobil.

2. Memudahkan Toko Automotive Filter Mobil dalam mengelola data transaksi penjualan dan laporan pemesanan filter mobil.

\section{KAJIAN PUSTAKA}

1. Website

Menurut Adhi (2010) [1] Website dapat diartikan sebagai "kumpulan halaman yang menampilkan informasi data teks, data gambar diam atau gerak, data animasi, suara, video dan atau gabungan dari semuanya, baik yang bersifat statis maupun dinamis yang membentuk satu rangkaian bangunan yang saling terkait dimana masing-masing dihubungkan dengan jaringanjaringan halaman (hyperlink)".

2.PHP ( Hypertext Preprocessor )

Menurut Edy, W., Zaki, A. dan Smitdev Community(2011) "2] "Sebuah bahasa pemograman web berbasis server (server-side) yang mampu mem-parshing kode php dari kode web dengan ektensi php, sehingga menghasilkan tampilan website yang dinamis di sisi client ( browser)"

3. MySQL

Menurut Anhar (2010) [3] "Perangkat lunak sistem manajemen basis data SQL atau DBMS dari sekian banyak DBMS seperti Oracle, MS SQL, Postgree SQL dan lain-lain”.

4. Pengembangan Perangkat Lunak

Menurut A.S. Rosa dan Shalahuddin, M, (2014) [4] "Model SDLC air terjun (waterfall) sering juga disebut sekuensial linier (sequential linier) atau alur hidup klasik (classis life cycle)". Model air terjun menyediakan pendekatan alur perangkat lunak secara sekuensial atau terurut dimulai dari analisa, desain, pengkodean, pengujian, dan tahap pendukung (support)".Berikut ini adalah ilustrasi model waterfall : 


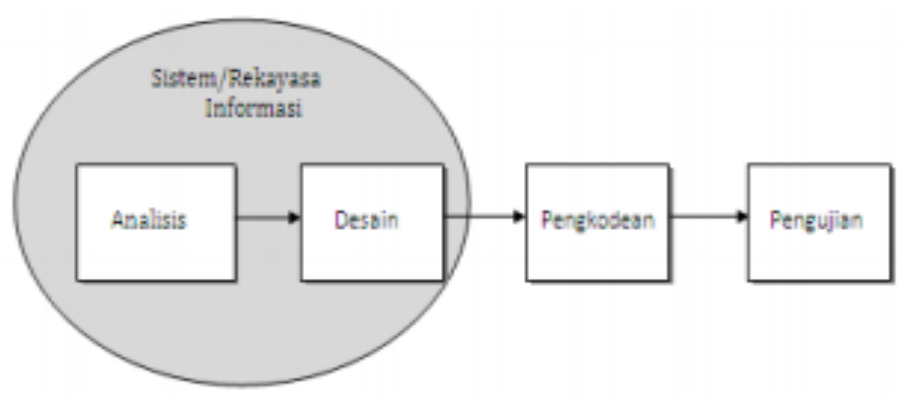

Gambar 1. Ilustrasi Model Waterfall

\section{ERD}

Menurut Fathansyah (2012) ${ }^{[5]}$ "Entity Relationship Diagram ( ERD ) adalah diagram yang berisi komponen- komponen himpunan entitas dan himpunan relasi yang masing-masing dilengkapi dengan atribut-atribut yang mempresentasikan seluruh fakta dari dunia nyata yang kita tinjau".

7. Pengujian Web

Menurut Shalahudin, M, dan A.S, Rosa(2011) ${ }^{[6]}$ "Black-Box Testing (pengujian Kotak Hitam) . Black-box yaitu menguji perangkat lunak dari segi spesifikasi fungsional tanpa menguji desain dan kode program. Pengujian dimaksudkan untuk mengetahui apakah fungsifungsi, masukan, dan keluaran dari perangkat lunak sesuai dengan spesifikasi yang dibutuhkan".

\section{PENELITIAN TERKAIT}

Beberapa penelitian yang terkait dengan topik penelitian yang dibahas antara lain :

1. Menurut Yuniva, Andriansah dan $\operatorname{Mubarok}(2019)^{[7]}$ dalam jurnalnya yang berjudul "Perancangan Web E-Commerce Pada Toko Helmet Fullface". Dalam penelitian ini menggunakan metode waterfall untuk pengembangan perangkat lunak, database MySQL dan bahasa pemograman menggunakan PHP dan HTML dalam membuat web. Dalam penelitian ini menjelaskan bahwa untuk mendapatkan helmet fullface diperlukan sebuah web $e$ commerce untuk mempermudah konsumen yang ingin membeli helmet fullface tanpa harus datang langsung ke Toko Helmet Fullface. Hasil dari penelitian ini menghasilkan sebuah web e-commerce untuk membantu Toko dalam mengelola transaksi penjualan dan laporan penjualan Helmet Fullface.

2. Menurut Yuniva dan Hestiyanto $(2018)^{[8]}$ dalam jurnalnya yang berjudul "Perancangan Web E-Commerce Untuk Penjualan Sepatu Dengan Pendekatan Model Classic Life Cycle". Dalam penelitian ini menggunakan pendekatan model Classic Life Cycle untuk metode pengembangan perangkat lunaknya, MySQL digunakan dalam merancang database dan tabel sedangkan dalam pembuatan web sricpt coding menggunakan bahasa pemograman PHP dan HTML. Dalam penelitian ini dijelaskan bahwa untuk membantu memasarkan produk, mempromosikan sepatu Home Industry Rizky Shoes dan meningkatkan pendapatan penjualan diperlukan sebuah website E-Commerce. 


\section{METODE PENELITIAN}

A. Teknik Pengumpulan Data

1. Observasi

Melalukan pengamatan pada sistem penjualan dan pemesanan yang ada di Toko Automotive Filter Mobil dan pada beberapa situs yang bersangkutan.

2. Studi pustaka

Melakukan studi pustaka dengan mengambil beberapa referensi yang berkaitan dengan permasalahan pada Toko Automotive Filter Mobil.

B. Metode Pengembangan Sistem

Metode yang digunakan pada pengembangan perangkat lunak ini menggunakan waterfall. Pada model ini terdapat beberapa tahapan yaitu :

1. Analisa Kebutuhan Sistem

Penulis melalukan pengamatan untuk mengumpulkan data yang dibutuhkan pada sistem penjualan filter mobil pada Toko Automotive Filter Mobil.

2. Desain

Penulis menggunakan ERD (Entity Relationship Diagram) untuk penggambaran model data dan menggunakan MYSQL dalam merancang database dan tabel.

3. Pengkodean

Dalam pembuatan script coding program penulis menggunakan bahasa pemograman PHP dan HTML.

4. Pengujian

Penulis menggunakan Black Box Testing terhadap rancangan web penjualan flter mobil untuk mengetahui apakah web yang telah dibuat sudah sesuai apa belum, agar tidak terjadi kesalahan pada saat dijalankan.

5. Support

Untuk menjalankan rancangan website penjualan filter mobil yang telah dibuat, diperlukan suatu hardware sebagai pendukung sistemnya, yaitu CPU, hardisk, monitor, mouse, keyboard. Sedangkan software pendukungnya yaitu sistem operasi Microsoft Windows, Database tool PhpMyadmin dan Web server Xampp.

\section{HASIL DAN PEMBAHASAN}

A. Analisa Kebutuhan Sistem

Analisa kebutuhan sistem pada rancangan website penjualan pada Toko Automotive Filter Mobil terdiri dari admin dan user.

1. Kebutuhan Admin

a. Admin dapat menambah atau mengganti password, username admin

b. Admin dapat menginput/menambah, menghapus, mengedit kategori filter mobil dan produk filter mobil

c. Admin dapat melihat dan menghapus data transaksi filter mobil yang masuk

d. Admin dapat mengubah status produk filter mobil

2. Kebutuhan User Pelanggan

a. User dapat melihat dan membeli produk filter mobil yang ada di halaman website

b. User dapat melihat filter mobil yang telah dipesan, mengubah jumlah filter mobil yang dipesan dan melanjutkan pemesanan dalam keranjang belanja.

c. User dapat melihat cara belanja dan pembayaran yang ada di halaman website. 
B. Desain

1. Rancangan Basis Data

Pada rancangan basis data terdiri dari beberapa tabel yaitu Barang, Pelanggan, Pemesanan, Kategori, Kota dan Pemesanan_Item.

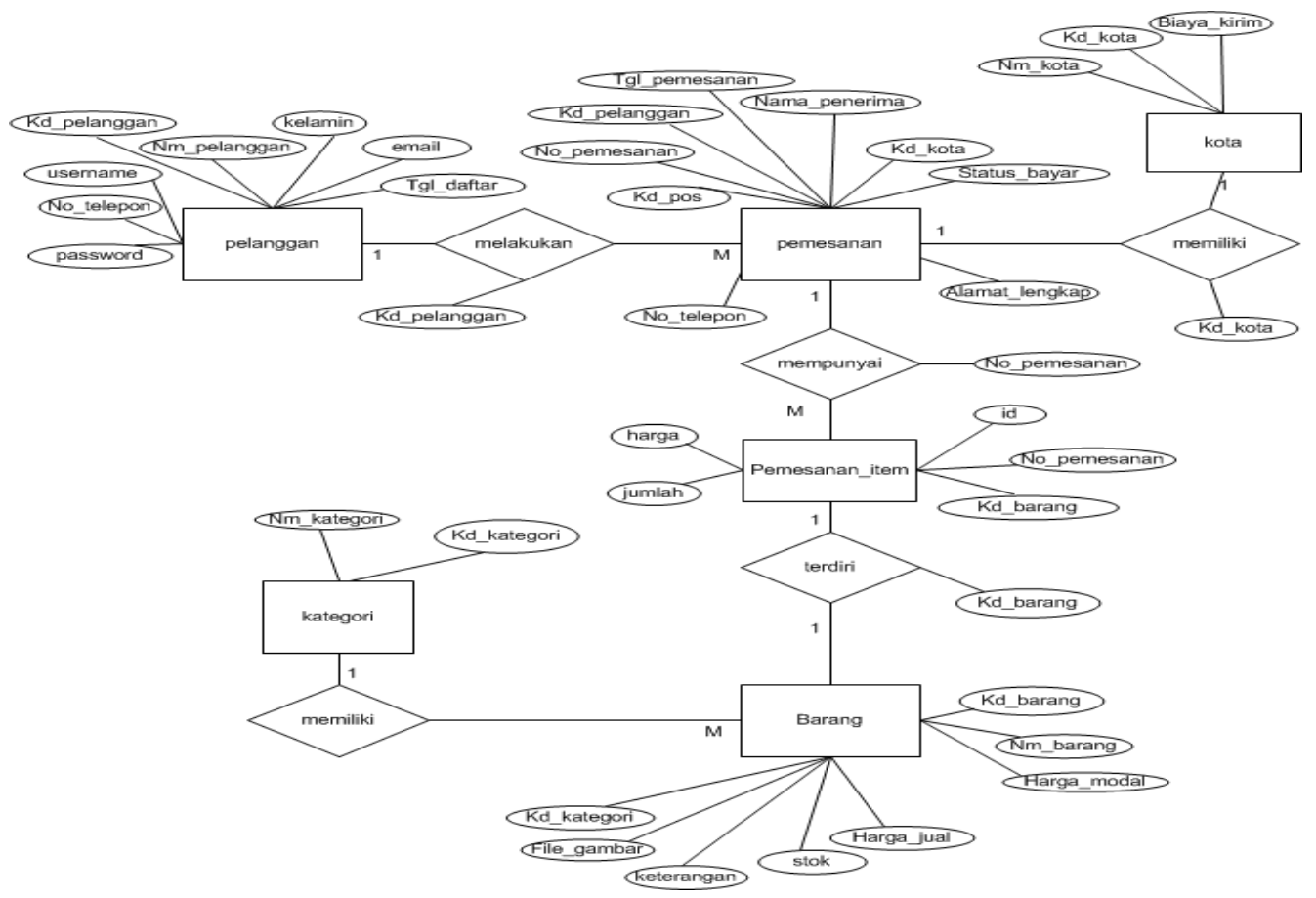

Gambar 2. ERD (Entity Relationship Diagram)

Berdasarkan gambar ERD diatas menjelaskan relasi antar tabel yaitu bahwa satu pelanggan dapat melakukan banyak pemesanan, satu kategori memiliki banyak barang dan satu pemesanan memiliki banyak item pemesanan.

2. Rancangan Antar Muka

Rancangan Website Penjualan Pada Toko Automotive Filter Mobil sebagai berikut :

a. Tampilan Halaman Login Admin

Administrator harus melakukan login terlebih dahulu untuk dapat menggunakan menu yang ada. Jika login berhasil maka akan tampil halaman utama admin.

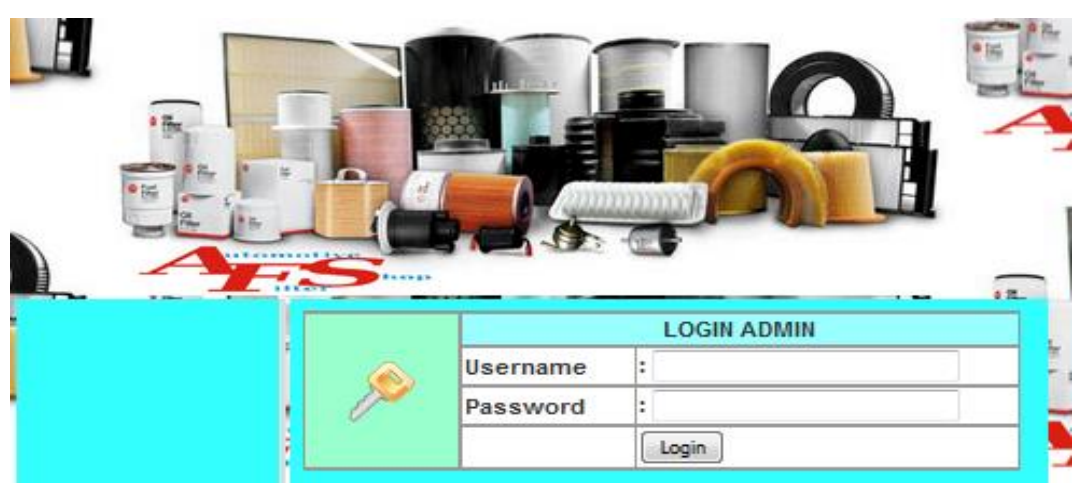

Gambar 3. Halaman Login Admin

b. Tampilan Halaman Utama Admin 
Setelah user berhasil melakukan login,maka user akan diarahkan ke halaman utama (index)Administrator. Pada halaman ini user nantinya dapat melakukan pengolahan data- data, seperti melihat, menambah ataupun merubah data produk melalui menu-menu yang tersedia.

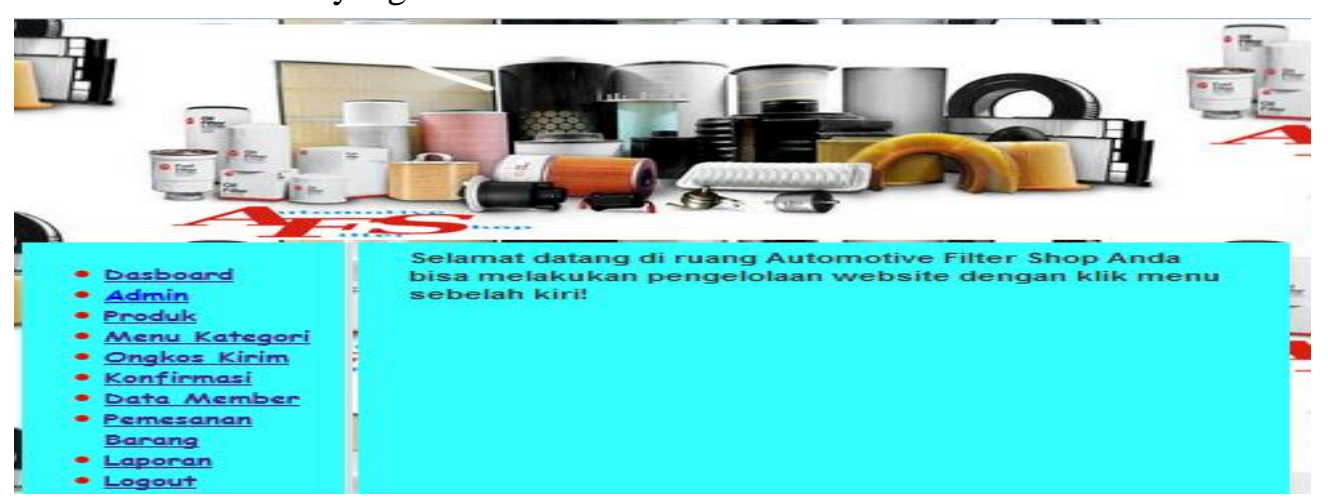

Gambar 4. Halaman Utama Admin

c. Tampilan Halaman Data Produk Filter Mobil

Setelah masuk ke menu data produk, admin dapat menambahkan data produk dan mengedit data produk.

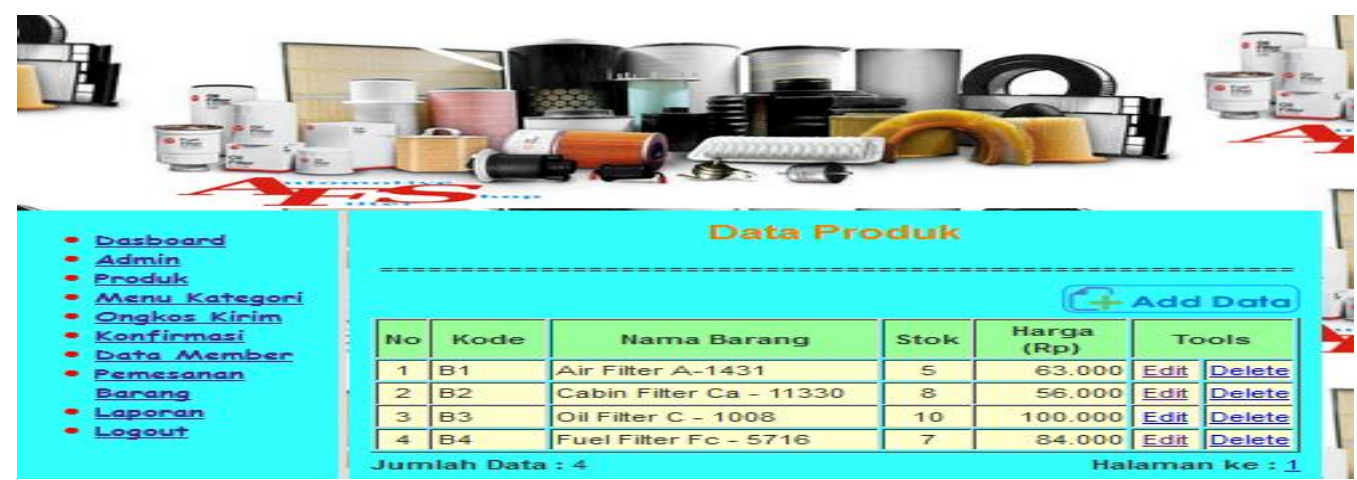

Gambar 5. Halaman Data Produk Filter Mobil

d. Tampilan Login Pelanggan

User pelanggan yang sudah melalukan daftar login terlebih dahulu untuk dapat. Melakukan pemesanan dan pembelian filter mobil. Jika login berhasil maka akan tampil halaman pelanggan.

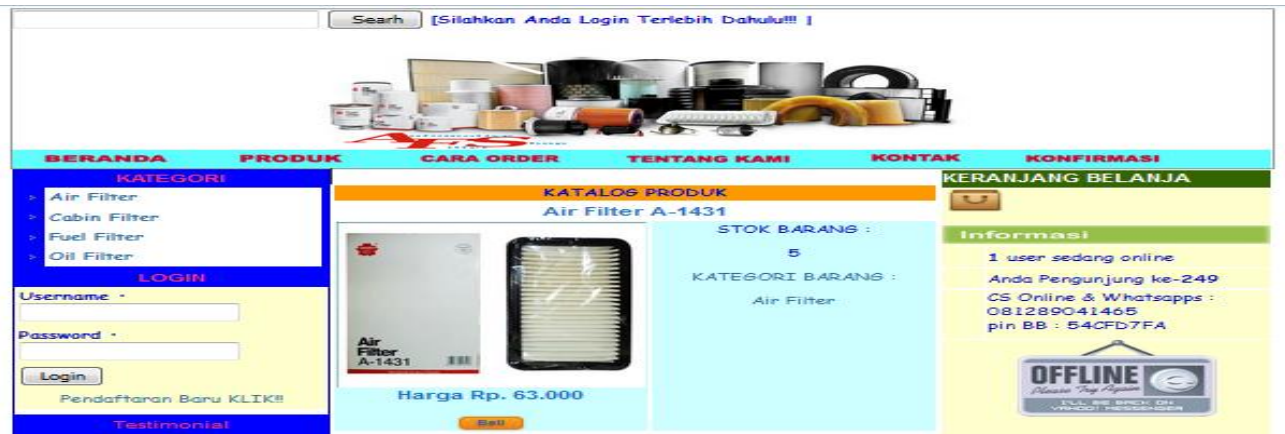

Gambar 6. Halaman Login Pelanggan

e. Tampilan Halaman Keranjang Belanja 
User yang telah mendaftar menjadi member atau pelanggan dapat melakukan proses pembelian filter mobil dan disimpan pada keranjang belanja.

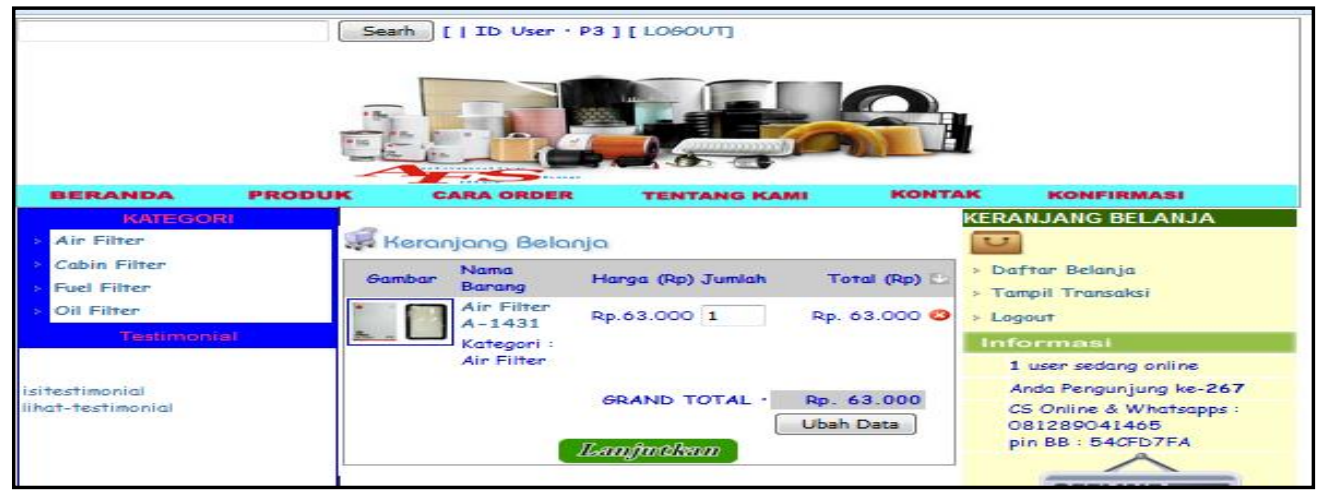

Gambar 7. Halaman Keranjang Belanja

f. Tampilan Halaman Laporan

Admin dapat melihat data laporan barang, pelanggan, pemesanan masuk dan pemesanan lunas.

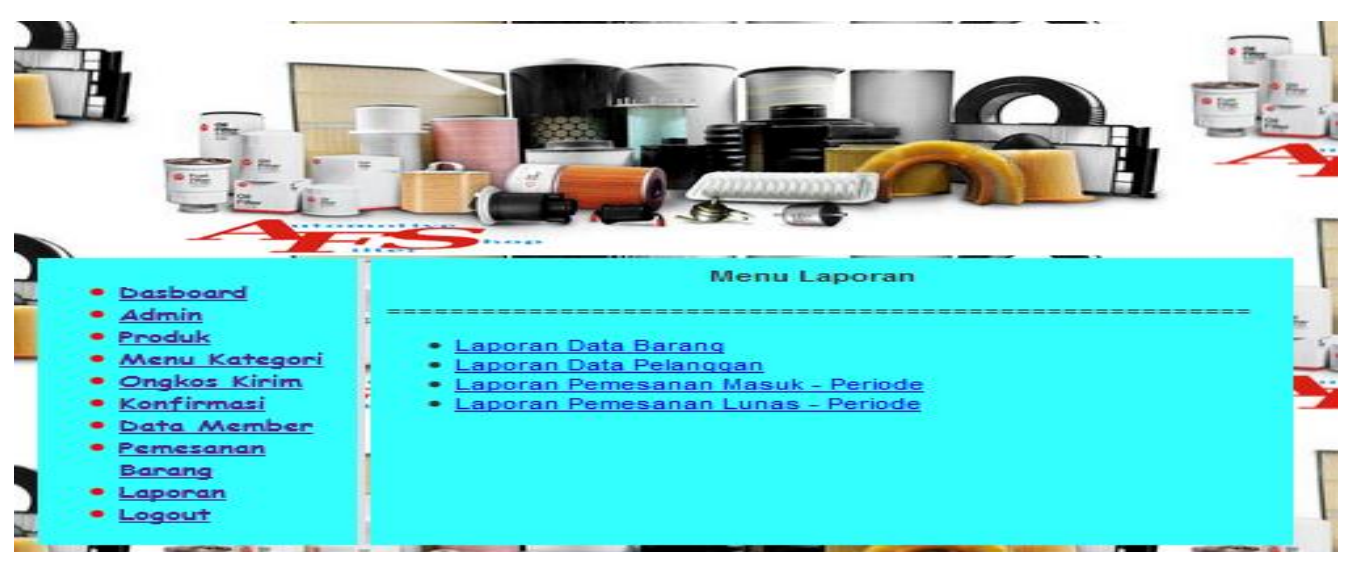

Gambar 8. Halaman Laporan

C. Pengujian

Pengujian terhadap rancangan website penjualan filter mobil yang dibuat menggunakan black box testing yang fokus terhadap proses masukan dan keluaran. Dan hasil black box testing sebagai berikut: 
Tabel 1. Pengujian terhadap login admin

\begin{tabular}{|c|c|c|c|c|c|}
\hline No & $\begin{array}{l}\text { Skenario } \\
\text { pengujian }\end{array}$ & Test Case & Hasil yang diharapkan & $\begin{array}{c}\text { Hasil } \\
\text { Pengujian }\end{array}$ & $\begin{array}{c}\text { Kesimp } \\
\text { ulan }\end{array}$ \\
\hline 1 & $\begin{array}{lr}\text { Username } & \text { dan } \\
\text { password } & \text { di } \\
\text { kosongkan } & \text { klik } \\
\text { tombol login } & \end{array}$ & $\begin{array}{l}\text { Username :kosong } \\
\text { Password : kosong }\end{array}$ & $\begin{array}{l}\text { LOGIN ANDA } \\
\text { SALAH ............ } \\
\text { Kesalahan Input : } \\
1 \text {. Data Username } \\
\text { kosong, silahkan isi } \\
\text { dengan benar } \\
2 \text {. Data Password } \\
\text { kosong, silahkan isi } \\
\text { dengan benar } \\
3 \text {. Data Username } \\
\text { dan Password yang } \\
\text { Anda masukan belum } \\
\text { benar }\end{array}$ & Sesuai harapan & Valid \\
\hline 2 & $\begin{array}{l}\text { Mengetikkan user } \\
\text { ID dan password } \\
\text { tidak diisi atau } \\
\text { kosong kemudian } \\
\text { klik tombol login }\end{array}$ & $\begin{array}{l}\text { Username : di isi } \\
\text { Password : kosong }\end{array}$ & $\begin{array}{l}\text { LOGIN ANDA } \\
\text { SALAH } \\
\text { Kesalahan Input : } \\
1 . . . . . . . . \\
\text { kosong, Data Password } \\
\text { dengan benar } \\
2 . \text { Data Username } \\
\text { dan Password yang } \\
\text { Anda masukan belum } \\
\text { benar }\end{array}$ & Sesuai harapan & Valid \\
\hline 3 & $\begin{array}{l}\text { Username tidak } \\
\text { diisi (kosong) dan } \\
\text { password diisi } \\
\text { kemudian klik } \\
\text { tombol login }\end{array}$ & $\begin{array}{l}\text { Username: diisi } \\
\text { Password : kosong }\end{array}$ & $\begin{array}{l}\text { Sistem akan menolak } \\
\text { akses user dan } \\
\text { menampilkan"data } \\
\text { username tidak boleh } \\
\text { kosong" }\end{array}$ & Sesuai harapan & valid \\
\hline 4 & $\begin{array}{l}\text { Mengetikkan salah } \\
\text { satu kondisi salah } \\
\text { pada username } \\
\text { atau password } \\
\text { kemudian klik } \\
\text { tombol login }\end{array}$ & $\begin{array}{l}\text { Username : diisi (salah) } \\
\text { Password : diisi (salah) }\end{array}$ & $\begin{array}{l}\text { LOGIN ANDA } \\
\text { SALAH } \\
\text { Kesalahan Input : } \\
1 \text {. Da...... } \\
\text { dan Password ysername } \\
\text { Anda masukan belum } \\
\text { benar }\end{array}$ & Sesuai harapan & valid \\
\hline 5 & $\begin{array}{l}\text { Mengetikkan } \\
\text { username dan } \\
\text { password dengan } \\
\text { data yang benar } \\
\text { kemudian klik } \\
\text { tombol login }\end{array}$ & $\begin{array}{l}\text { Username : diisi (benar) } \\
\text { Password: diisi (benar) }\end{array}$ & $\begin{array}{l}\text { Sistem menerima akses } \\
\text { login dan kemudian } \\
\text { langsung menampilkan } \\
\text { menu utama }\end{array}$ & Sesuai harapan & valid \\
\hline
\end{tabular}

Tabel 2. Pengujian terhadap Halaman Daftar user member atau pelanggan 


\begin{tabular}{|c|c|c|c|c|c|}
\hline No & Skenario & Test Case & Hal yang diharapkan & $\begin{array}{c}\text { Hasil } \\
\text { Pengujian }\end{array}$ & $\begin{array}{c}\text { Kesimp } \\
\text { ulan }\end{array}$ \\
\hline 1 & $\begin{array}{lr}\text { User } & \text { mendaftar } \\
\text { sebagai member } \\
\text { atau pelanggan } \\
\text { dengan email } \\
\text { yang } & \text { sudah } \\
\text { pernah } & \text { di } \\
\text { daftarkan } & \end{array}$ & $\begin{array}{l}\text { Mendaftar dengan email } \\
\text { yang sudah ada terdaftar } \\
\text { pada sistem }\end{array}$ & $\begin{array}{l}\text { Sistem akan menolak } \\
\text { dan menampilkan " } \\
\text { maaf email yang anda } \\
\text { daftarkan sudah ada } \\
\text { pada sistem }\end{array}$ & $\begin{array}{l}\text { Sesuai } \\
\text { harapan }\end{array}$ & Valid \\
\hline 2 & $\begin{array}{l}\text { User mendaftar } \\
\text { sebagai member } \\
\text { atau pelanggan } \\
\text {,mengisi field } \\
\text { pendaftaran } \\
\text { dengan } \\
\text { mengosongkan } \\
\text { field nama }\end{array}$ & $\begin{array}{l}\text { Mendaftar } \\
\text { member atau pelanggan } \\
\text { Salah satu field } \\
\text { dikosongkan }\end{array}$ & $\begin{array}{l}\text { Sistem akan menolak } \\
\text { dan menampilkan } \\
\text { pesan "anda belum } \\
\text { mengisikan nama" }\end{array}$ & $\begin{array}{l}\text { Sesuai } \\
\text { harapan }\end{array}$ & Valid \\
\hline 3 & $\begin{array}{l}\text { User mendaftar } \\
\text { sebagai } \\
\text { memberatau } \\
\text { pelanggan dan } \\
\text { mengisikan } \\
\text { semua field } \\
\text { dengan benar }\end{array}$ & $\begin{array}{l}\text { Mendaftar sebagai } \\
\text { member atau pelanggan } \\
\text { Semua field diisi dengan } \\
\text { benar }\end{array}$ & $\begin{array}{ll}\text { Sistem akan } \\
\text { menerima } \\
\text { pendaftaran,dan akan } \\
\text { masuk ke menu } \\
\text { utama web }\end{array}$ & $\begin{array}{l}\text { Sesuai } \\
\text { harapan }\end{array}$ & Valid \\
\hline
\end{tabular}

\section{KESIMPULAN}

Penulis mencoba menarik kesimpulan dari pembahasan sebelumnya yaitu :

1. Dengan adanya Rancangan Website Penjualan pada Toko Automotive Filter Mobil ini diharapkan dapat dan memudahkan pelanggan dalam memesan dan membeli filter mobil.

2. Mempermudah pengelola sebuah Toko Automotive Filter Mobil untuk memasarkan produk filter mobil.

3. Mempermudah Toko Automotive Filter Mobil dalam pengelolaan data transaksi pemesanan filter mobil dan meningkatkan penjualan.

\section{SARAN}

Penulis memberikan beberapa saran yang dapat menjadi tolak ukur untuk meningkatkan tampilan dalam perancangan website penjualan filter mobil yang lebih baik. Berikut saran-saran yang dapat penulis berikan :

1. Diperlukan adanya backup data untuk mencegah kehilangan data akibat kelalaian manusia ataupun kesalahan sistem.

2. Perlu adanya penambahan fitur pada tampilan wesbiste yang menarik lebih banyak pengunjung.

3. Diharapkan adanya update security untuk keamanan sebuah website.

\section{DAFTAR PUSTAKA}

[1] Adhi, P., 2010, Cara Mudah Membuat Desain Web Untuk Pemula,. Media Kita, Jakarta

[2] Edy, W., Zaki, A. dan Smitdev Community, 2011, Resep Top PHP Untuk Programmer Pemula, Elex Media Komputindo, Jakarta.

[3] Anhar, 2010, Panduan Menguasai PHP \& MySQL Secara Otodidak, Jakarta, Media Kita 
[4] A.S. Rosa dan Shalahudin, M, 2014, Rekayasa Perangkat Lunak Terstruktur dan Berorientasi Objek, Bandung, Informatika

[5] Fathansyah, 2012, Basis Data., Informatika, Bandung

[6] Shalahudin, M, dan A.S, Rosa, 2011, Java di Web, Informatika, Bandung

[7] Yuniva, I, Andriansah, dan Mubarok, I.P, 2019, Perancangan Web E-Commerce Pada Toko Helmet Fullface, Jurnal INTI Nusa Mandiri, Jakarta, Vol.13, No.2, Hal 9-14.

[8] Yuniva, I dan Hestiyanto, D, 2018, Perancangan Web E-Commerce Untuk Penjualan Sepatu Dengan Pendekatan Model Classic Life Cycle, Jurnal CERITA(Creative Education Of Research In Information Technology And Artificial), Raharja Tangerang, Vol.4, No.1, Hal 24-33. 